\title{
STRATEGI PEMASARAN PRODUK MAKANAN RINGAN KHAS RIAU (KERIPIK NENAS DAN RENGGINANG UBI KAYU)
}

\author{
YENI KUSUMAWATY \\ Jurusan Agribisnis Fakultas Pertanian Universitas Riau \\ Kampus Binawidya Simpang Baru Kecamatan Tampan Pekanbaru \\ yeni.kusumawaty@lecturer.unri.ac.id
}

\begin{abstract}
ABSTRAK
Pemerintah Daerah Provinsi Riau berkomitmen menjadikan Riau sebagai tujuan wisata berbasis Budaya Melayu di Asia Tenggara pada tahun 2020. Salah satu tulang punggung pariwisata adalah produk makanan tradisional diantaranya makanan ringan (snack food), seperti keripik. Penelitian ini menggunakan metode deskriptif dalam bentuk studi kasus di dua unit usaha skala rumah tangga: (1) keripik nenas "Berkat Bersama" di Desa Kualu Nenas, Kecamatan Tambang, Kabupaten Kampar dan (2) rengginang ubi kayu di Kecamatan Tenayan Raya Kota Pekanbaru. Penelitian ini bertujuan: (1) Mengkaji strategi pemasaran (bauran pemasaran) produk keripik nenas dan rengginang ubi kayu; (2) Memberikan saran pemasaran alternatif untuk produk keripik nenas dan rengginang ubi kayu. Kesimpulan penelitian adalah: (1) Umumnya produk dinilai baik oleh konsumen, dan telah memiliki lima unsur strategi produk yaitu atribut produk, merek, kemasan, dan label tetapi variasi citarasa produk dan tampilan kemasan perlu ditingkatkan terutama untuk rengginang ubi kayu; (2) Strategi penetapan harga produk keripik nenas dan rengginang ubi kayu ditetapkan oleh produsen berdasarkan pendekatan orientasi biaya. Untuk ke depan perlu dipertimbangkan penetapan harga dengan melihat faktor harga produk pesaing; (3) Strategi promosi keripik nenas dan rengginang ubi kayu masih terbatas, Aspek promosi dalam penjualan pribadi (personal selling) telah dilakukan; (4) Keripik nenas dan rengginang terutama dipasarkan melalui pedagang pengecer (75 persen) dan langsung kepada konsumen (25 persen) sehingga produsen memiliki posisi tawar lebih lemah karena ketergantungan yang tinggi kepada pengecer karena keterbatasan modalnya.
\end{abstract}

Kata kunci: industri rumah tangga, makanan ringan, keripik nenas, rengginang ubi kayu, bauran pemasaran

\begin{abstract}
Riau Provincial Government is committed to make Riau as a tourism destination based on Malay Culture in Southeast Asia in 2020. One of the backbone of tourism is traditional food product including snack foods such as chips/crackers. This research applied descriptive method in the form of case study at two home scale business units: (1) pineapple chips "Berkat Bersama" in the village of Kualu Nenas, Tambang Subdistrict, Kampar Regency and (2) cassava rengginang (crackers) in Tenayan Raya Pekanbaru City. This study was aimed to: (1) examine marketing strategy (marketing mix) product of pineapple chips and cassava rengginang; (2)) Providing alternative marketing advice for pineapple chips and cassava rengginang products. The research conclusions are: (1) The product is generally considered good by consumers, and has the five elements of prod-uct strategy that are product, brand, packaging and label attributes but variations of flavor and packaging ap-pearance need to be improved especially for cassava rengginang; (2) The pricing strategy of pineapple chips and cassava rengginang is determined by the manufacturer based on cost orientation approach. In
\end{abstract}

124 | Strategi Pemasaran Produk Makanan Ringan Khas Riau (Keripik Nenas Dan Rengginang Ubi Kayu) 
the future, it is necessary to consider the pricing by looking at the price of competitors' products; (3) The strategy of promotion of pineapple chips and cassava rengginang is still limited. The promotion aspect of personal selling has been conducted; (4) Pineapple and rengginang chips are mainly marketed through retailers (75 percent) and directly to consumers (25 percent) so that producers have a weaker bargaining position due to their high dependence on retailers due to their limited capital.

Keywords: home industry, snack food, pineapple chips, cassava rengginang, marketing mix

\section{PENDAHULUAN}

Provinsi Riau terletak di wilayah geografis yang strategis di jalur perdagangan dunia dengan kekayaan kuliner yang bervariasi. Maka Pemerintah provinsi Riau berusaha terus mengembangkan daerah ini sebagai destinasi pariwisata dengan visi 2020 "The Homeland of Malays" yaitu menjadikan kawasan Riau destinasi pariwisata berbasis Budaya Melayu di Asia Tenggara (Nurwanto, 2016).

Salah satu ciri khas adalah produk makanan tradisional sebagai cenderamata. Peningkatan permintaan terhadap produk makanan khas Riau tergambar dari pembukaan sejumlah gerai yang menjual berbagai makanan tradisional khas Riau. Produksi ritel makanan merupakan salah satu potensi industri rumah tangga terbesar kedua setelah pertanian (Wijaya, 2013).

Produk pangan yang populer adalah berupa makanan ringan (snack food), dan salah satu jenis snack yang dikembangkan sebagai oleh-oleh adalah keripik. Menurut Sulistyowati (2004), keripik adalah makanan ringan jenis crackers yang bersifat kering, renyah (crispy) dan kandungan lemaknya relatif tinggi. Produk keripik digemari karena teksturnya yang khas, citarasanya lezat, tahan lama, praktis dibawa dan disimpan.

Di Provinsi Riau, salah satu produk keripik yang cukup berkembang adalah keripik nenas di desa Kualu Nenas, Kabupaten Kampar. Kabupaten Kampar telah dikenal sebagai pusat penghasil nenas. Menurut data statistik Kampar dalam angka 2013, produksi nenas di Kampar mencapai 2.150 ton per tahun. Dari jumlah itu, sekitar 1.050 ha berada di Desa Kualu Nenas dengan produksi rata-rata 121 ton per bulan. Saat ini terdapat sekitar 20 industri rumahan olahan nenas (Pratama, 2016).

Selain buah nenas, potensi lain di Riau adalah ubi kayu. Menurut Elida dan Hamidi (2009), tanaman ubi kayu cocok dikembangkan di Provinsi Riau dengan kondisi lahan yang relatif kering. Secara umum luas panen ubi kayu cenderung menurun karena pengusahaan kelapa sawit, tetapi dengan banyaknya lahan marginal yang cocok untuk ditanami ubi kayu, 
potensi ubi kayu masih dapat ditingkatkan dengan mengolahnya menjadi produk makanan bernilai tambah lebih tinggi.

Usaha Mikro Kecil Menengah (UMKM) masih banyak mengalami kendala diantaranya terbatasnya akses terhadap sumberdaya produktif; keterbatasan kapasitas produksi dan spesifikasi produk (KUMKM, 2006). Menurut Ariani dan Dwiyanto (2013), pemasaran dan pendistribusian produk makanan skala kecil mengalami kesulitan, karena pasar bagi industri kecil pengolahan makanan dikuasi oleh beberapa perusahaan besar sehingga menyulitkan perusahaan kecil untuk bersaing. Nilai tambah produk masih kurang, dan banyak UMKM tidak memiliki izin produksi serta aspek pengemasan kurang menarik.

Daya saing berpengaruh signifikan terhadap peningkatan produktivitas dan memperluas akses pasar. Hal ini akan bermuara kepada peningkatan omset penjualan dan profitabilitas perusahaan (Rahmana dalam Larasati 2011). Secara umum, UMKM di Indonesia kalah bersaing dengan industri skala besar karena kurang memperhatikan aspek pemasaran. Padahal, banyak kasus menunjukkan bahwa sebuah produk menerapkan teknologi sederhana tetapi mendapat respons baik dari konsumen karena pemasarannya efektif.

Untuk mengembangkan potensi makanan-makanan tradisional Riau sebagai daya tarik daerah, dibutuhkan kajian ilmiah terutama pada aspek pemasarannya yaitu strategi bauran pemasaran (marketing mix). Pemilihan makanan tradisional Riau yang dikaji pada penelitian ini yaitu produk keripik nenas dan rengginang ubi kayu karena produk ini merupakan makanan selingan (snack) yang populer sebagai oleh-oleh. Penelitian ini bertujuan:

1. Mengkaji strategi pemasaran (bauran pemasaran) produk keripik nenas dan rengginang ubi kayu

2. Memberikan saran pemasaran alternatif untuk produk keripik nenas dan rengginang ubi kayu

\section{METODE PENELITIAN}

Penelitian ini menggunakan metode deskriptif berupa studi kasus di dua unit usaha skala rumah tangga (home industry), yaitu: (1) keripik nenas "Berkat Bersama" di Desa Kualu Nenas, Kecamatan Tambang, Kabupaten Kampar provinsi Riau dan (2) rengginang ubi kayu di Kecamatan Tenayan Raya Kota Pekanbaru.

Metode deskriptif digambarkan Saputra (2016) dan Nawawi (2001) sebagai langkahlangkah representasi obyektif tentang gejala-gejala dalam masalah yang diselidiki. Ciri pokok 
metode deskriptif: (1) memusatkan perhatian pada masalah aktual, dan (2) menggambarkan fakta-fakta sebagaimana adanya, diiringi interpretasi rasional. Ini sesuai tujuan penelitian untuk memperoleh fakta tentang makanan ringan khas Riau.

Untuk mengkaji aspek pemasaran, teknik pengambilan sampel yang digunakan adalah purposive sampling terhadap pemasar produk keripik nenas dan rengginang ubi kayu. Pemasar yang menjadi sampel pada penelitian ini adalah toko makanan tradisional Riau AlMahdi sebagai pemasar dengan perkiraan omset terbesar di Kota Pekanbaru.

Data penelitian ini terdiri dari data primer dan data sekunder. Data sekunder meliputi karakteristik produk dan proses pemasarannya dari instansi terkait dan literatur. Data primer diperoleh dari wawancara menggunakan kuesioner kepada produsen dan pemasar produk keripik nenas dan rengginang ubi kayu.

Analisis data pada penelitian ini dilakukan dengan tabulasi dan pengelompokan data primer dari pemasar dan produsen dan dianalisis secara deskriptif kualitatif untuk menggambarkan bauran pemasaran (marketing mix) produk keripik nenas dan rengginang ubi kayu yang meliputi strategi produk, harga, promosi dan distribusi dan merumuskan strategi bauran pemasaran alternatif.

\section{HASIL DAN PEMBAHASAN}

\section{Profil Agroindustri Keripik Nenas "Berkat Bersama"}

Agroindustri skala rumah tangga (home industry) "Berkat Bersama" di Desa Kualu Nenas, Kecamatan Tambang, Kabupaten Kampar Riau dimiliki oleh Bapak Muslimin yang telah menjalankan usaha ini selama 15 tahun dan telah bergabung dalam Asosiasi Pangan Riau (ASPARI).

Bahan baku pembuatan keripik nenas adalah buah nenas segar, minyak goreng, dan garam. Dengan demikian produk keripik nenas yang dihasilkan bersifat alami tanpa tambahan bahan pengawet. Alat yang digunakan berupa penggorengan vakum. Bahan baku untuk pembuatan keripik nenas diperoleh dari kebun nenas milik produsen dan dibeli dari petani di sekitar lokasi agroindustri.

Produksi keripik nenas diawali dengan pengupasan dan pemotongan buah nenas, kemudian pencucian, penggorengan secara vakum dan setelah itu ditiriskan. Selanjutnya keripik nenas siap untuk dikemas dalam kantong plastik atau kemasan kotak dengan berat bersih 150 gram. 


\section{Profil Agroindustri rengginang ubi kayu merk "Rosa"}

Agroindustri rengginang ubi kayu diproduksi di Kecamatan Tenayan Raya di Jalan Utama No. 45 Rejosari Kulim Pekanbaru. Produk yang dihasilkan berupa Rengginang ubi kayu. Ubi yang telah dikupas lalu dicuci, kemudian diparut, lalu dilakukan pemerasan pati sampai kering, selanjutnya tepung pati diberi bumbu bawang putih, garam, dan kaldu lalu diaduk sehingga siap dicetak, kemudian tahap penjemuran dan setelah kering siap untuk dikemas dan dipasarkan.

Rengginang ubi kayu diproduksi oleh Ibu Rosa dan telah berjalan selama 10 tahun. Peralatan yang digunakan masih tradisional sehingga membutuhkan waktu lama dalam pembuatan. Industri ini telah terdaftar di Depertemen Kesehatan, tetapi belum mendapat sertifikat label kehalalan dari MUI (Majelis Ulama Indonesia). Industri ini tergabung dalam Himpunan Kerajinan Makanan dan Miuman Riau (HIKMARI).

\section{Strategi Pemasaran}

Pemasaran merupakan kegiatan manusia yang diarahkan untuk memenuhi kebutuhan dan keinginan konsumen melalui pertukaran. Pemasaran harus dapat menafsirkan kebutuhan konsumen dan mengkombinasikan dengan data pasar seperti: lokasi konsumen dan kesukaan mereka (Anggrahini dan Surwati 2014).

Menurut Dharmmesta dan Handoko (2012), marketing mix atau bauran pemasaran adalah kombinasi dari empat variabel yaitu produk, struktur harga, kegiatan promosi, dan sistem distribusi. Keempat unsur bauran pemasaran tersebut saling berhubungan dan berpengaruh satu sama lain, sehingga harus diupayakan untuk menghasilkan suatu kebijakan pemasaran yang mengarah kepada layanan efektif.

\section{Strategi Produk}

Produk merupakan segala sesuatu yang dapat ditawarkan produsen untuk diperhatikan, diminta, dicari, dibeli, digunakan atau dikonsumsi pasar sebagai pemenuhan kebutuhan atau keinginan pasar (Mevita dan Suprihhadi, 2013). Berdasarkan penggolongan produk menurut Kotler (2009), produk makanan termasuk keripik nenas dan rengginang ubi kayu tergolong pada produk tidak tahan lama (non durable goods) yang cepat habis dikonsumsi.

\subsection{Atribut produk}


Pengembangan suatu produk melibatkan penentuan manfaat yang diberikan yang dinilai dari kualitas dan fitur produk. Rancangan kualitas produk merupakan kemampuan produk untuk dapat melaksanakan fungsinya meliputi daya tahan produk (Badariyansyah, 2008). Keripik nenas tergolong produk konsumen yaitu produk yang selain dibeli untuk konsumsi pribadi juga sebagai oleh-oleh.

Produk keripik nenas hanya terdiri dari satu jenis rasa yaitu rasa orisinal dan belum memiliki variasi ukuran kemasan karena dijual dalam bentuk kemasan 150 gram. Keripik nenas memiliki daya tahan sekitar 3-4 bulan. Kemasan produk menampilkan atribut masa expired (kadaluwarsa) produk, komposisi produk, label halal, izin Dinas Kesehatan dan kadar nutrisi keripik nenas.

Produk Rengginang ubi kayu juga terdiri dari satu rasa yaitu rasa asin gurih. Produk ini mempunyai daya tahan sekitar 1 bulan, namun belum mencantumkan tanggal expire (kadaluarsa) pada kemasan dan belum ada mendapat label halal dari MUI walaupun telah mendapat izin dari Depkes RI.

\subsection{Pemberian Merek (Branding)}

Merek memiliki peran yang signifikan pada kemajuan perusahaan. Merek bukan sekedar nama suatu produk, tetapi sangat menentukan pada kondisi persaingan yang meningkat, karena konsumen akan mengenali merek terlebih dahulu. Bahkan dapat dikatakan bahwa merek merupakan sesuatu yang dibeli oleh konsumen (Utami, 2007).

Pemberian merek dari keripik nenas "Berkat Bersama" berawal dari kreativitas pemilik usaha untuk menciptakan nama yang unik agar membawa berkat bagi masyarakat karena pada saat itu nenas belum banyak dijadikan keripik. Saat ini merek dari keripik nenas "Berkat Bersama" sudah cukup dikenal oleh masyarakat. Produk keripik nenas belum memiliki perluasan lini produk seperti variasi rasa dan bentuk produk.

Rengginang ubi kayu yang berawal saat Ibu Rosa sebagai pengrajin, mendapat binaan dari Disperindag Kota Pekanbaru. Merk yang digunakan adalah "Rengginang Ubi Kayu” yang mencerminkan jenis produk makanan ringan tersebut.

\subsection{Pengemasan}

Pengemasan (packing) melibatkan kegiatan, merancang dan memberi wadah atau pembungkus suatu produk. Menurut Fakultas Ekonomi dan Bisnis Unsoed (2018), tidak 
semua pelaku bisnis menyadari bahwa kemasan produk yang mereka tawarkan ternyata memberikan pengaruh besar terhadap penjualan produk. Apalagi para pelaku usaha kecil yang saat ini banyak bermunculan, umumnya hanya fokus untuk menciptakan suatu produk namun tidak memperhatikan kemasan produk yang digunakannya. Kemasan yang sering digunakan hanyalah kemasan plastik biasa yang tidak berbeda dengan pelaku bisnis lain.

Kemasan produk keripik nenas yang digunakan dibedakan dalam dua jenis yaitu kemasan kotak dan plastik dengan ukuran yang sama (150) gram yang telah diberi label produk. Keripik nenas dikemas dengan plastik kemudian dimasukkan dalam kemasan kotak. Sebagian produk yang dijual langsung ke konsumen tanpa melalui toko pengecer ada yang dikemas dalam kantong plastik berlabel sesuai permintaan. Tapi pada umumnya dalam penjualan lebih banyak memakai kemasan kotak karena lebih menarik.

Rengginang ubi kayu untuk kemasan produk makanan ini belum memadai dalam pengemasan. Sebagai agroindustri yang masih tradisional, kemasan produk berupa kantong plastik yang transparan, karena untuk membuat kemasan yang lebih modern dengan alasan biaya. Kondisi kemasan rengginang yang sederhana sesuai dengan kajian Indrawijaya (2012) di Kota Jambi, bahwa kemasan makanan ringan umumnya masih sederhana dengan logo kurang mampu menarik konsumen dan kurang informatif.

\subsection{Pemberian label (Labelling)}

Kemasan adalah faktor yang dapat mempengaruhi konsumen dalam keputusan pembelian. Maka kemasan harus mampu menjadi media informasi, baik secara verbal maupun secara visual diantaranya melalui label makanan. Informasi secara verbal antara lain mencakupi komposisi produk (pada produk makanan atau minuman), informasi halal, batas kadaluarsa dan sebagainya. Sedangkan informasi dalam bentuk visual dapat ditampilan melalui tipografi, warna dan gambar (Nugrahani, 2015).

Label keripik nenas menampilkan merek produk "Berkat Bersama", gambar dua buah nenas masak berwarna orange dengan tulisan "pineapple chips", label halal, berat bersih (netto) 150 gram, alamat produksi, dan kandungan keripik nenas. Label halal dikeluarkan oleh Majelis Ulama Indonesia (MUI). Alamat produksi yaitu Keripik nenas Berkat Bersama Kualu Nenas Kecamatan Tambang Kabupaten Kampar-Riau-Indonesia. Komposisi keripik nenas terdiri dari lemak 1,90 persen, karbohidrat 29,06 persen, dan gula 7,73 persen. 
Pemberian label Rengginang ubi kayu sangat sederhana, berupa label bergambar bunga dengan merek "ROSA", informasi komposisi produk rengginang ubi kayu, alamat usaha di Jl. Utama No. 45 Rejosari Kulim-Pekabaru dan label dari Dinkes. Kemasan yang digunakan oleh Usaha agroindustri Rengginang ubi kayu masih sederhana berupa kantung plastik transparan.

\section{Strategi Harga}

Harga adalah nilai jual yang ditetapkan oleh penjual terhadap sesuatu yang dibeli, oleh konsumen, berdasarkan keinginan untuk mendapatkan keuntungan. Pada umumnya konsumen membeli pada toko eceran yang menawarkan berbagai macam produk dengan harga yang bersaing, minimal sesuai dengan kualitas produk. Harga secara implisit mempunyai hubungan dengan kualitas. Kualitas produk yang baik akan dijual dengan harga tinggi sedangkan produk dengan kualitas kurang baik akan dijual dengan harga relatif rendah. Dalam realitasnya, harga mempunyai pengaruh terhadap kepuasan konsumen (Shabastian dan Samuel, 2013).

Strategi harga terdiri dari orientasi biaya, orientasi terhadap permintaan dan orientasi harga kompetitor. Penetapan harga keripik nenas oleh agroindustri Berkat Bersama adalah berdasarkan biaya produksi. Harga keripik nenas yang dijual langsung oleh produsen adalah Rp.14.000, sedangkan untuk keripik nenas yang dijual kepada pengecer memiliki harga yang berbeda tergantung besarnya biaya angkut, sedangkan harga yang diterapkan toko Al-Mahdi sebagai pengecer kepada pembeli keripik nenas adalah Rp 17.000/kotak.

Agroindustri rengginang ubi kayu untuk harga makanan ini ditentukan penjual berdasarkan biaya-biaya produksi dalam pembuatan rengginang ubi kayu. Adapun harga makanan ini dijual produsen seharga Rp.3.500/bungkus. Sedangkan untuk rengginang ubi kayu yang telah sampai kepada para pengecer dijual dengan harga yang berbeda, dari harga para pengecer seperti gerai Al-Mahdi tempat peneliti memperoleh data. Rengginang ubi kayu dijual dengan harga Rp. 6.000/bungkus.

\section{Strategi Promosi}

Promosi adalah bentuk komunikasi pemasaran yang berupa aktivitas pemasaran yang berusaha menyebarkan informasi, mempengaruhi atau membujuk, dan mengingatkan 
produknya agar dapat menerima, memberi, dan loyal kepada produk yang ditawarkan perusahaan yang bersangkutan (Aryanti, 2016).

Strategi promosi (promotional mix) yang dapat dilakukan antara lain berupa periklanan (advertising), penjualan pribadi (personal selling), promosi penjualan (sales promotion), dan publisitas (publicity). Bentuk strategi promosi diantaranya: (1) Periklanan (melalui media televisi, radio, surat kabar, spanduk, brosur, kalender; (2) Promosi penjualan melalui kupon diskon/ undian pada momen tertentu, lomba, potongan harga; (3) Hubungan masyarakat dan publisitas (misalnya melalui seminar, lokakarya, workshop); (4) Penjualan personal misalnya sales promotion; (5) Pemasaran langsung (misal delivery order dan presentasi) (Amanah, 2015).

Strategi promosi saat ini untuk keripik Nenas berupa pemasangan papan nama usaha di depan unit usaha. Pernah juga dilakukan promosi melalui televisi yaitu di Riau TV (Rtv) yang dampaknya permintaan kosumen meningkat. Tapi produsen keripik nenas tidak sanggup untuk memasang iklan di televisi ini, karena biaya yang tinggi. Promosi insidentil dilakukan melalui kegiatan seminar produk lokal di sejumlah organisasi. Tetapi kegiatan promosi yang dominan untuk Keripik Nenas adalah promosi antar individu.

Rengginang Ubi Kayu dalam usaha kegiatan promosi yang dilakukan sangat minim sekali hampir dikatakan tidak ada hanya pernah saja diperkenalkan oleh Dinas Perindustrian dan perdagangan dalam kegiatan-kegiatan pameran, Sedangkan dari Produsen Sendiri baru bisa dari individu keindividu saja. Dalam kegiatan promosi seperti televisi, surat kabar atau baleho pengusaha belum sanggup untuk melakukan jenis promosi ini.

Secara umum, kegiatan promosi untuk produk makanan ringan produk home industry ini dilakukan terutama dalam bentuk komunikasi dari individu ke individu (personal selling). Jika dilihat dari model periklanan yang terjadi, ini mengikuti sebuah model dari promosi publik relations release yaitu suatu tujuan bisnis adalah untuk menciptkan kondisi para pelanggan yang merasa puas. Terciptanya kepuasan pelanggan dapat memberikan beberapa manfaat, diantara hubungan antara perusahaan dan pelanggan menjadi harmonis, memberikan dasar yang baik bagi pembelian ulang, dan terciptanya loyalitas pelanggan, sehingga membentuk suatu rekomendasi dari mulut kemulut (word of mouth) yang menguntungkan bagi perusahaan (Tjiptono, 1997).

Sedangkan menurut pemasar dari informasi yang terjadi dari pemintaan konsumen makanan khas Riau ini, dari berbagai aneka makanan khas Riau yang dijual untuk saat ini 
permintaan konsumen selalu meningkat. Kemudian juga dari pengusaha sendiri dengan terjadi image yang baik bagi usahanya sangat berdampak positif dalam penjualan produknya.

\section{Strategi Distribusi}

Strategi distribusi merupakan jalur yang dilalui oleh arus barang dari produsen ke perantara dan sampai kepada konsumen. Menurut Permana et al. (2013), distribusi meliputi saluran distribusi, lokasi pemasaran, dan sarana transportasi untuk mengantarkan produk ke konsumen.

Sebagai bagian dari bauran pemasaran, distribusi dapat diartikan sebagai kegiatan pemasaran yang berusaha mempermudah penyampaian barang dari produsen kepada konsumen. Distribusi merupakan kegiatan yang sangat penting dalam pemasaran karena dengan distribusi yang efektif barang akan cepat dipasarkan dan dibeli dan dikonsumsi oleh konsumen. Semua perusahaan perlu melakukan fungsi distribusi karena bertugas menyampaikan barang yang diperlukan konsumen (Ardiyanta, 2013).

Keputusan mengenai saluran distribusi merupakan hal yang penting bagi sebuah perusahaan. Pendistribusian Keripik Nenas sampai ke konsumen dilakukan dengan kendaraan pribadi atau kendaraan umum. Pendistribusian produk tidak hanya dilakukan di Kota Pekanbaru saja, namun sampai ke pengecer di Jakarta, dan sebagian pengecer dari luar kota menjual ke Malaysia dengan langsung mengambil ke tempat produsen.

Strategi distribusi yang dilakukan agroindustri keripik nenas agar produk sampai ketangan konsumen yaitu distribusi langsung dan tidak langsung. Saluran distribusi dari produsen langsung dijual ke pengecer, lalu dari pengecer dijual ke konsumen. Pendistribusian juga langsung dilakukan kepada konsumen, tapi yang dominan dilakukan langsung ke pengecer dengan biaya antar ditanggung pembeli dan transaksi secara sistem beli putus.

Agroindustri rengginang ubi kayu memasok bahan bakunya langsung dari para petani di daerah Kulim. Strategi pendistribusian secara tidak langsung melalui para pengecer, kemudian dari pengecer sampai ke konsumen. Penyaluran barang dari tempat usaha dilakukan sendiri oleh pemilik usaha dengan menggunakan kendaraan pribadi, tetapi pada umumnya banyak pengecer yang langsung menjemput barang tersebut di tempat usaha produsen dengan melakukan pemesanan terlebih dahulu.

Rengginang ubi kayu yang dijual selalu cepat habis tidak menunggu waktu lama sehingga untuk peluang pasar masih terbuka luas. Namun kondisi tersebut belum dapat 
dimanfaatkan secara maksimal, karena peralatan yang digunakan dalam memproduksi rengginang ubi kayu belum memadai, dan masih kekurangan tenaga kerja dikarenakan modal yang masih kurang, kemudian cara memproses makanan tersebut masih bersifat tradisional. Saluran pemasaran rengginang ubi kayu yang paling dominan langsung ke konsumen, kemudian melalui pengecer.

Walaupun permintaan selalu banyak namun produksi rengginang ubi kayu ini belum bisa diproduksi setiap hari, hanya dua hari sekali disebabkan peralatan masih tradisional, dan permodalan yang terbatas sehingga pengrajin belum mampu membeli peralatan modern. Maka peluang pasar rengginang ubi kayu ini masih terbuka. Saluran distribusi untuk kedua produk makanan ringan khas Riau dapat dilihat pada gambar 1.

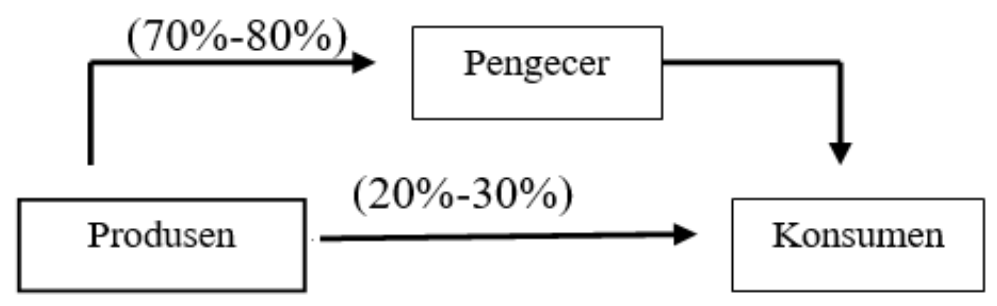

Gambar 1. Bagan saluran distribusi makanan ringan khas Riau

\section{Alternatif Strategi}

Untuk strategi produk keripik nenas sudah cukup baik begitu juga atribut produk yang ditampilkan pada kemasan, sehingga kualitas produk harus dipertahankan secara konsisten. Alternatif strategi produk keripik nenas adalah meningkatkan variasi produk karena belum adanya diversifikasi produk seperti rasa, bentuk, dan ukuran kemasan. Untuk rengginang ubi kayu disarankan meningkatkan tampilan label dan kemasan serta melakukan pengurusan label halal. Strategi ini sesuai kajian Wantini et al. (2013) bahwa produk makanan harus mempertahankan kualitas untuk menjaga kepercayaan konsumen dan tampilan kemasan jika ditingkatkan dapat berfungsi sebagai alat promosi.

Untuk strategi harga, agroindustri keripik nenas dan rengginang ubi kayu menetapkan harga jual produk berdasarkan orientasi terhadap biaya produksi. Namun dengan adanya strategi penetapan harga yang lain selain orientasi pada biaya dan meningkatnya persaingan usaha, produsen dapat menjajaki kemungkinan ke depan untuk mempertimbangkan orientasi 
harga terhadap permintaan dan orientasi harga kompetitor dengan harapan dapat terus bertahan dalam persaingan pasar.

Dari kegiatan promosi yang dilakukan selama ini oleh agroindustri keripik nenas dan rengginang ubi kayu masih terbatas dan belum rutin. Terkait hal ini, beberapa kegiatan promosi yang dapat dilakukan selain advertising (iklan) dan personal selling (penjualan pribadi) diantaranya kerjasama rutin dengan Dinas Perindustrian untuk melakukan pameran produk (bazar) dan publisitas dalam surat kabar lokal, website pemerintah daerah dan melalui brosur produk di daerah tujuan wisata di Provinsi Riau. Saat ini semakin banyak perusahaan yang berkomitmen meningkatkan kepuasan pelanggan.

Pentingnya pemasaran dalam meraih kepuasan pelanggan diantaranya (Tjiptono, 1997) bahwa: (1) tujuan bisnis adalah untuk menciptakan pelanggan yang puas. Kepuasan pelanggan dapat meningkatkan hubungan antara perusahaan dan pelanggan, mendorong pembelian ulang, dan terciptanya loyalitas pelanggan, sehingga terjadi rekomendasi dari mulut ke mulut (word of mouth); (2) kepuasan atau ketidakpuasan pelanggan adalah respon pelanggan terhadap ketidaksesuaian (disconfirmation) yang dirasakan antara harapan sebelumnya dan kinerja aktual produk; (3) kepuasan pelanggan merupakan tanggapan emosional pada evaluasi terhadap konsumsi suatu produk.

Saluran pemasaran yang dilakukan adalah langsung ke konsumen dan ke pedagang pengecer (Gambar 1). Strategi pemasaran yang saat ini dilakukan masih terbatas walaupun pemasaran produk telah sampai ke beberapa kota. Dalam kegiatan pemasaran pada umumnya terdapat beberapa saluran pemasaran atau tingkat distribusi. Menurut Kotler (1987) dalam Simanjuntak (2008), umumnya ada empat saluran pemasaran, yaitu: (1) saluran tingkat nol (saluran langsung/zero level channel) dimana produsen menjual langsung ke konsumen; (2) saluran tingkat satu (one level channel) yang terdiri dari satu perantara; (3) saluran tingkat dua yang terdiri dari dua perantara. dan (4) saluran tingkat tiga; terdiri dari tiga perantara, berupa pedagang pengumpul (grosir), pedagang besar (pemborong), dan pengecer.

Industri makanan ringan khas Riau hanya memakai saluran tingkat nol dan satu, sehingga kurang mempromosikan produknya kepada konsumen. Untuk ke depan, produsen dapat bekerja sama dengan pemasar untuk merancang promosi yang terjangkau seperti iklan cetak dan radio, dan pembagian sampel produk. Selain itu, produsen perlu mempertahankan dan meningkatkan mutu produk, sehingga promosi dari mulut ke mulut (word of mouth) oleh 
konsumen terus berjalan. Ini sesuai dengan kajian Arbainah (2010) bahwa pelanggan yang puas akan menyebarkan opini yang positif (positive word of mouth).

\section{KESIMPULAN DAN SARAN}

\section{Kesimpulan}

1. Dari aspek produk, makanan ringan khas Riau yaitu keripik nenas dan rengginang ubi kayu tergolong produk spesial yang umumnya dibeli sebagai cendera mata.

2. Strategi penetapan harga produk keripik nenas dan rengginang ubi kayu ditetapkan oleh produsen berdasarkan pendekatan orientasi biaya. Untuk ke depan perlu dipertimbangkan penetapan harga dengan melihat faktor harga produk pesaing.

3. Strategi promosi keripik nenas dan rengginang ubi kayu masih terbatas sedangkan aspek promosi dalam penjualan pribadi (personal selling) telah dilakukan.

4. Untuk aspek distribusi, keripik nenas dan rengginang terutama dipasarkan melalui pedagang pengecer ( 75 persen) dan langsung kepada konsumen ( 25 persen).

5. Kondisi produsen makanan cemilan khas Riau ini umumnya memiliki posisi tawar lebih lemah dan ketergantungan yang tinggi kepada pengecer karena keterbatasan modalnya, yang menjurus kepada pola hubungan patron-client.

\section{Saran}

Produk makanan khas daerah memiliki potensi yang besar termasuk dalam menunjang pariwisata di Provinsi Riau, maka Pemerintah Daerah Kota Pekanbaru dan Provinsi Riau diharapkan memberikan dukungan kepada produsen yang tergolong usaha kecil menengah untuk menjadikan produk makanan khas Riau sebagai kebanggaan daerah Riau dan menajdi daya tarik wisata kuliner dan sebagai produk cinderamata untuk dibawa ke luar daerah Riau.

\section{DAFTAR PUSTAKA}

Anggrahini, Devi dan Surwati, C.H.D. 2014. Kegiatan Komunikasi Pemasaran Rown Division dalam Media Sosial (Studi Deskriptif Kualitatif Mengenai Kegiatan Komunikasi Pemasaran Rown Division di Solo melalui Media Sosial Facebook dan Twitter dalam Meningkatkan Jumlah Konsumen). http://www.jurnalkommas.com/docs/JURNAL-Devi\%20Anggrahini.pdf (diakses 17 Mei 2017)

Arbainah, S. 2010. Studi Tentang Words of Mouth (WOM) Positif pada Bisnis Ritel Pasar Modern (Kasus Empiris pada Minimarket Alfamart dan Indomaret di Kota Semarang). Thesis Program Studi Magister Manajemen Universitas Diponegoro Semarang. 
Ardiyanta, O. 2013. Analisis Strategi Distribusi untuk Meningkatkan Volume Penjualan pada PT Salma Nusantara. Tugas Akhir pada Program Studi Akuntansi DIII Fakultas Ekonomi Universitas Negeri Yogyakarta.

Anggreni, F. dan Praptiningsih, M. 2013. Pengelolan dan Pengembangan Usaha Distribusi makanan Ringan pada CV Timur Jaya Raya di Lombok - Nusa Tenggara Barat. Jurnal AGORA 1(2): 10 halaman.

Amanah, S. 2015. Peranan Strategi Promosi Pemasaran Terhadap Peningkatan Volume Penjualan. Jurnal LENTERA 3(1): 47-55.

Ariani, Desi dan Dwiyanto, B.M. 2013. Analisis Pengaruh Supply Chain Management Terhadap Kinerja Perusahaan (Studi Pada Industri Kecil dan Menengah Makanan Olahan Khas Padang Sumatera Barat). Diponegoro Journal of Management 2(3):110.

Aryanti, N.M. 2016. Fungsi Promosi Produk Pos Ekspress dalam Meningkatkan Minat Konsumen di Kota Bandung. Skripsi Universitas Pasundan.

Dharmmesta, B.S. dan Handoko, T.H. 2012. Manajemen Pemasaran Analisis Perilaku Konsumen. Edisi Pertama. BPFE, Yogyakarta

Fakultas Ekonomi dan Bisnis Unsoed. 2018. Pentingnya Kemasan Produk. Diunduh dari http://feb.unsoed.ac.id/id/article/pentingnya-kemasan-produk

Indrawijaya, S. 2012. Pengaruh Kemasan Terhadap Keputusan Konsumen dalam Pembelian Produk Industri Kecil Makanan Ringan pada Supermarket di Kota Jambi. Jurnal Manajemen Terapan dan Keuangan 1(1):33-38.

Kotler, P. dan Armstrong. 2009. Prinsip-Prinsip Pemasaran. Penerbit Erlangga, Jakarta.

KUMKM. 2006. Hambatan Usaha Kecil dan Menengah dalam Kegiatan Ekspor. Jurnal Pengkajian Koperasi dan UKM 1(1):99-112.

Larasati, B.H. 2011. Analisis Hubungan Komunikasi Pemasaran dengan Kualitas Daya Saing Usaha Mikro Kecil Menengah (UMKM) Studi pada UMKM mitra binaan IPB. Skripsi UT Communication and Community Development.

Diunduh dari epository.ipb.ac.id/handle/123456789/47337 tanggal 5 November 2017.

Maharani, E., Edwina, S. dan Kusumawaty, Y. 2010. Strategi Pengembangan Agroindustri Nata de coco di Kabupaten Indragiri Hilir. Jurnal IJAE 1(1):75-86

Mevita, A.S dan Suprihhadi, H. 2013. Pengaruh Bauran Pemasaran Terhadap Kepuasan Konsumen. Jurnal Ilmu \& Riset Manajemen 2(9):1-18. file:///C:/Users/User/Downloads/363-1488-1-PB.pdf (diakses 19 Mei 2017).

Moscardo, G. 2004 Shopping as a destination attraction: An empirical examination of the role of shopping in tourists' destination choice and experience. Journal of Vacation Marketing 10(4):294-307.

Nawawi, H. H. 2001. Metode Penelitian Bidang Sosial. Gajah Mada University Press. Yogyakarta.

Nugrahani, R. 2015. Peran Disain Grafis pada Label dan kemasan Produk Makanan UMKM. Jurnal Imajinasi 12(2):127-136.

Nurwanto. 2016. Pariwisata Riau, Intan Yang Mulai Bersinar. Diunduh dari http://riaugreen.com/view/Ruang-Opini/21672/Pariwisata-Riau--Intan-Yang-Mulai-

137 | Strategi Pemasaran Produk Makanan Ringan Khas Riau (Keripik Nenas Dan Rengginang Ubi Kayu) 
Bersinar.html\#.WmPjsqiWbIU tanggal 5 Januari 2018.

Oktavina, R. 2009. Model Manajemen Strategis Evaluasi Kinerja Usaha Mikro dan Kecil Makanan Ringan. Jurnal Ekonomi Bisnis 2(14):88-102.

Permana, I.M.R., Suamba, I.K. dan Wijayanti, P.U. 2013. Bauran Pemasaran Bunga Krisan pada Kelompok Usaha Bersama Manik Mekar Nadi di Desa Besakih, Kecamatan Rendang, Kabupaten Karangasem. E-Jurnal Agribisnis dan Agrowisata 2(1):12-22

Pratama, I. 2016. Varian Nenas Menopang Perekonomian Masyarakat Kampar. Riau Bertuah Online 5 Maret 2016. http://riaubertuah.co/varian-nenas-menopang-perekonomianmasyarakat-kampar/ (Diakses 17 Mei 2017)

Roostika, R. 2012. Analisis Pengaruh Bauran Pemasaran Produk Cindera Mata terhadap Kepuasan Wisatawan Domestik di Yogyakarta. Jurnal Manajemen dan Akuntansi 1(3): 104-116.

Saputra, A.H.N.P. 2016. Analisis Efektivitas Komunikasi Pemasaran pada Produk Yogurt Sentulfresh Indonesia Melalui Website. Skripsi Departemen Sains Komunikasi dan Pengembangan Masyarakat Fakultas Ekologi Manusia Institut Pertanian Bogor.

Shabastian, M. dan Samuel, H. 2013. Pengaruh Strategi Harga dan Strategi Produk Terhadap Brand Loyalty di Tator Café Surabaya Town Square. Jurnal Manajemen Pemasaran 1(1): $1-9$

Simanjuntak, R. 2008. Analisis Pemasaran Tahu di Kota Madya Pekanbaru. Skripsi Fakultas Pertanian Universitas Riau, Pekanbaru. (tidak dipublikasikan)

Utami, T.N. 2007. Sikap Mahasiswa terhadap Merk Lokal: Studi pada Mahasiswa Pemakai Kosmetik Sariayu. Jurnal Iqtishoduna 3(1):16 halaman.

Sulistyowati, A. 2004. Membuat Kripik Buah dan Sayur. Penerbit Puspa Swara, Depok.

Tjiptono. 1997. Strategi Pemasaran Edisi II. Penerbit Andi, Yogyakarta.

Wantini, S., Martono, T. dan Hindrayani, A. 2013. Pengaruh Bauran Pemasaran terhadap Keputusan Pembelian Emping Mlinjo di Kelurahan Ngadirejo Kecamatan Kartasura. Jurnal Pendidikan Bisnis dan Ekonomi (BISE) 1(1): 67-79

Wijaya, A.A. 2013. Analisis Strategi Pemasaran Makanan Tradisional: Studi Kasus Pada Home Industry Rengginang Halimatus Sa'diyah Kalibaru di Kabupaten Banyuwangi. Skripsi Fakultas Ekonomi Universitas Jember. 